\title{
Calvo, Thomas. Espadas y plumas en la Monarquia hispana: Alonso de Contreras y otras vidas de Soldados (1600-1650), Casa de Velázquez, 2020, 334 pp.
}

Osvaldo Victor Pereyra

DOI: https://doi.org/10.24215/23468971e129

Universidad Nacional de La Plata, Argentina

vopereyra@gmail.com

Recepción: 18 Febrero 2020

Aprobación: 12 Abril 2020

Sin duda, el libro de Thomas Calvo debe ser considerado un trabajo inteligente, por momentos vibrante y lleno de vida pues, como el mismo autor sostiene, se intenta "ligar a los individuos con su geografía, su universo político, sus sociedades -el contexto en su conjunto-... (p.4)", partiendo para ello del "espacio vital” del capitán Alonso de Contreras (1582-1645). Este militar y escritor español, nacido en Madrid a fines del siglo XVI, fue autor de unas memorias tituladas Vida, nacimiento, padres y crianza del capitán Alonso de Contreras, natural de Madrid Cavallero del Orden de San Juan, Comendador de una de sus encomiendas en Castilla, cuyo original se encuentra depositado en Biblioteca Nacional de Madrid. Una vida dedicada a servir a una Monarquía Hispánica de trazos universales. Es decir, la vida de un soldado, de un militar, que tal vez no alcance la dimensión introspectiva de otros cultivadores del género autobiográfico como San Agustín, Abelardo o Teresa de Jesús; o la dimensión política de memorias tales como las de Samuel Pepys, Saint Simon, o Leonora Christina Ulfeldt, etc., pero que sin duda, nos permiten componer una serie de bisectrices tejidas entre el espacio de una vida al servicio de la corona y la administración y defensa del Imperio. Al fin y al cabo, la historia está hecha por los hombres, en muchos casos comunes, que a través de sus vivencias y experiencias nos permiten captar esa unidad de sentido entre lo particular y lo universal, tal cual nuestra profesión requiere.

La primera parte (vida de soldados: el imperio a río revuelto) el autor nos compone en presentarnos el derrotero vital de Contreras, sus orígenes humildes de "cristiano viejo" y sus primeras aventuras, con su partida a los Países Bajos cuando apenas contaba con quince años. Su participación en acciones de corso, en Berbería y el Levante, y su incorporación en Malta a la Orden de San Juan. Su lucha contra los turcos, y la intervención en varias incursiones navales en territorios de la frontera oriental del Imperio. En 1603 alcanza el grado de alférez y en 1616 el de capitán. Al servicio de Manuel Alonso de Zúñiga y Acevedo marcha a Sicilia, atendiendo así a los servicios militares del Virrey. Es decir, momentos finales de un siglo XVI brillante para las armas españolas, con la constitución de un Imperio dilatado, la obtención de un lugar central en la política europea y, a la vez, a partir de 1580, la incorporación de Portugal y sus colonias. Un impero Ibérico -gracias a las exitosas alianzas matrimoniales- que permite recomponer el cuadro de posiciones de los Habsburgo a nivel europeo y mundial. Pero también, el tránsito al siglo XVII, un momento mucho más oscuro, que enfrenta a nuestro personaje con trances que superan su humilde humanidad ¿Sí ya hay señales de que la Providencia abandona a España? ¿Sí el peso del Imperio fuera excesivo? Los problemas no dejarán de presentarse uno tras otro, los frentes abiertos eran demasiados, las columnas crujen, como lo señala Quevedo, coetáneo de Alonso de Contreras, con cierto dejo de lamentación: "miré los muros de la patria mía, si en un tiempo fuertes, ya desmoronados...” Sin duda, angustia sí, pero también buen momento para repasar la memoria de otros tiempos. Tal vez ello impulsa, en alguna medida, a nuestro capitán a repasar pormenorizadamente, como actor vivencial, una vida de servicios y con ello, acompañar, al posible lector, a posar la mirada sobre los hechos y los hombres que formaron parte de estas empresas. ¿Cómo no dejar memoria escrita de los logros y las hazañas realizadas por este oscuro hidalgo madrileño? Pero, como el propio 
T. Calvo señala, no hay un "árbol”, sino un "bosque de vidas". Por lo pronto no es únicamente nuestro capitán, en su estudio exploratorio el autor ha reunido las obras o vidas escritas por siete soldados -si se quiere de poca monta- que relatan con su propia pluma sus experiencias vitales en el tránsito temporal del siglo XVI al XVII. Así encontramos a Diego Suárez (1552-1622), Jerónimo de Pasamonte (1553-1622/1626), Diego Galán (1675-1648), Diego Duque de Estrada (1659-1649), Miguel de Castro (1590-1617?) y Domingo de Toral Valdés (1598-1635?). Tal vez en esta lista, como aclara el autor, falte Miguel de Cervantes -sin duda el más célebre de los militares-escritores- de no ser por el caso de que él no escribió su biografía, aunque en toda su obra aparezcan, aquí y allá, retazos de su experiencia. Tal como su Quijote sintetiza frente a los dichos del joven paje soldado: "a la guerra me lleva, mi necesidad; si tuviera dineros, no fuera, de verdad", así como la respuesta "más quiero tener por amo y por señor al rey, y servirle en la guerra, que no un pelón en la corte" (p. 44).

En la segunda parte (los socorros de Filipinas 1613-1620. El fracaso de un gran designio Imperial) el autor nos adentra en las "entrañas del monstruoso Leviatán..." en donde desfilan, uno a uno, claramente descriptos, los intereses geopolíticos de monarquía, así como los económicos -siempre presentes en estas empresas militares y comerciales- entre España, Asia y la Nueva España. Nuevamente los relatos del Discurso de mi vida, de Alonso de Contreras nos guían por esos sinuosos mares plagados de aventuras, o desventuras si se prefiere. Así aparecen hombres de negocios como Horacio de Levanto, quien interviene claramente en la empresa de armado de estos tres "socorros" entre los años 1613, 1617 y 1619. Así se nos asoman actores claves como "el tal veedor de armas o el duque de Medina Sidonia, o el príncipe Filiberto de Saboya o don Alonso Fajardo, general de la armada... (y) gobernador de Filipinas” (p. 84). Es decir, hombres, planes, proyectos, intrigas personales, etc., una intrincada red y urdimbre de intereses personales mezclados en estas empresas fundamentales para mantener la integridad del Imperio. Su relato, claro y ameno, nos permite obtener una visión del enmarañado archipiélago de réditos, muchas veces personales, que determinaban o condicionaban aquello que denominamos la política imperial.

La tercera parte (Una vida después del discurso de mi vida) nos compone a un Contreras ya entrado en años, probando "fortuna en la Indias" y siendo enviado a la provincia de Sinaloa, donde transita su historia entre los continuos levantamientos indígenas en este espacio de frontera y las tensiones propias de los militares y moradores españoles asentados en ese espacio, así como las continuas controversias suscitadas con las autoridades y superiores, mostrando con ello las dificultades propias de la administración y gobierno que pesaban sobre las espaldas de nuestro capitán.

Finalmente, la cuarta parte (Mundos nuevos, mismos Universos) marca el fin de un libro, pero también de una vida, o al revés, el paso a la melancolía imperial, como el lector quiera componerlo. Una experiencia vital que nos ha "paseado" por la espacialidad dilatada del Imperio Ibérico, en momentos particulares de su existencia como entidad política de orden mundial, o global, como hoy está de moda decir. De Madrid a Flandes, de Malta a Egipto, a Filipinas, a Sinaloa, etc., pero también, e indirectamente, de Constantinopla y Orán a Goa y Manila. Vidas, espacios e Imperio ordenados en términos de recorridos vitales que se apiñan, se enmarañan unos con otros, se comunican entre sí.

Del Levante al Poniente, puntos extremos de unas carreras militares que aún tienen mucho para contarnos en una historia que hoy intenta pensarse más en sus conexiones plurales. Es de celebrar tal hecho, en un libro con muchísimas virtudes.

\section{BY-NC-SA}

